\title{
GAMBARAN ASUHAN KEPERAWATAN DIMENSI SPIRITUAL DI RUANGAN KARDIOVASKULER RSUD ARIFIN ACHMAD
}

\author{
Safri $^{1}$,Sofiana Nurchayati ${ }^{2}$, Siti Rahmalia ${ }^{3}$ \\ ${ }^{1,2,3}$ Fakultas Keperawatan Universitas Riau \\ Email: safri@ lecturer.unri.ac.id \& nursingsyariah9@gmail.com
}

\begin{abstract}
Abstrak
Kebutuhan spiritual adalah suatu kebutuhan yang bersifat universal dan merupakan bagian dari kebutuhan dasar manusia yang harus dipenuhi. Tujuan penelitian ini adalah untuk mengetahui gambaran asuhan keperawatan dimensi spiritual pada pasien gangguan kardiovaskuler. Desain penelitian yang digunakan adalah deskriptif sederhana untuk mengetahui gambaran asuhan keperawatan dimensi spiritual di ruang kardiovaskuler RSUD Arifin Achmad. Sampel dalam penelitian ini dengan menggunakan teknik total sampling dengan jumlah 16 responden yaitu perawat di ruang CVCU RSUD Arifin Achmad yang memenuhi kriteria inklusi. Hasil penelitian ini diketahui $81,3 \%$ selalu meminta pasien untuk berdoa demi kesembuhannya, 87,5 \% selalu mengucapkan salam sebelum masuk ke ruang perawatan, $68,8 \%$ selalu berbagi perasaan dengan pasien di ruang perawatan, 31,3\% selalu mengorientasikan fasilitas ibadah yang tersedia di Rumah Sakit, 68,8 \% selalu menyusun bersama pasien tentang rencana ritual ibadah yang akan dilaksanakan selama pasien dirawat, 68,8 \% selalu melakukan pengkajian dimensi spiritual pasien, 68,8 \% selalu mengangkat diagnosa keperawatan dimensi spiritual pasien, namun tidak dilakukan pencatatan yang benar pada rekam medis pasien. Perawat yang bekerja di unit kardiovaskular sebenarnya telah memberikan asuhan keperawatan dimensi spiritual yang sebaiknya dicatat dalam Rekam Medis. Diharapkan perawat dapat meningkatkan kompetensi intervensi keperawatan spiritual.
\end{abstract}

Keywords: Spiritual, Asuhan Keperawatan, Virginia Handerson, Kardiovaskuler.

\begin{abstract}
Spiritual needs are a universal need and are part of the basic human needs that must be met. The purpose of this study was to determine the description of spiritual dimension nursing care in patients with cardiovascular disease. This simple descriptive study using total sampling methode on nurse cardiovascular unit in Arifin Achmad Hospital. The result this study 81, 3\% always ask the patient to pray for his recovery, $87.5 \%$ always say hello before entering the intervention ward, $68.8 \%$ always share feelings with patients in the room, $31.3 \%$ always orient the facilities available at cardiovascular unit, $68.8 \%$ always plan with patients about the ritual worship will be implemented, $68.8 \%$ always assessment and nursing diagnosis the spiritual dimension of the patient, but do not record in medical record pasient. The nurse in cardiovasvular has given nursing care dimension spiritual, but must be recorded in Medical Record. It is expected that a nurse to can improve the competence of spiritual nursing interventions.
\end{abstract}

Keywords: Spiritual, Nursing Care, Virginia Handerson, Cardiovascular

\section{PENDAHULUAN}

Sistem Kardiovaskular atau sistem peredaran darah yang terdiri dari darah, pembuluh darah dan organ utama jantung bekerja untuk mendistribusikan darah ke seluruh tubuh untuk menyediakan oksigen dan nutrisi (seperti asam amino dan elektrolit) ke semua sel serta membuah sampah metabolik dan karbon dioksida dari jaringan. Anatomi jantung terletak di dalam mediastinum di rongga dada. 2/3 nya terletak di bagian kiri, 1/3 nya terletak di bagian kanan dari garis 
Safri $^{1}$, Sofiana Nurchayati ${ }^{2}$, Siti Rahmalia ${ }^{3}$,Gambaran Asuhan Keperawatan Dimensi Spiritual Di Ruangan Kardiovaskuler Rsud Arifin Achmad

tengah tubuh. (Rokhaeini, 2001;Moser \& Riegel, 2008 dalam Safri, 2014).

Penyakit Kardiovaskular yang paling sering terjadi adalah hipertensi, disritmia, penyakit jantung koroner (PJK) dan atau berakhir pada gagal jantung. Di Indonesia penyakit Kardiovaskular tersebut juga mengalami peningkatan, hal ini dibuktikan oleh data yang di catat oleh Rumah Sakit Jantung dan Pembuluh Darah Harapan Kita (RSJPDHK) yang merupakan salah satu rujukan nasional sehingga dapat mewakili angka kejadian gangguan Kardiovaskular di Indonesia. Pada tahun 2013 angka yang paling tinggi dirawat di Rumah Sakit Jantung Pusat Nasional Harapan Kita adalah Acute Coronary Syndrome sebanyak 3186 orang dimana data masuk melalui UGD, dengan rincian UAP 1206 kasus, NSTEMI 719 kasus, STEMI 896 kasus dan APS 456, disusul oleh gagal jantung yang terdiri dari CHF sebanyak 662 kasus kemudian ADHF 1932 kasus (Safri, 2014)

Berdasarkan pendekatan model konsep teori Virginia Henderson yang dikenal dengan 14 dasar kebutuhan pasien, pasien dengan gangguan Kardiovaskular, kebutuhan fisiologis adalah hal utama yang harus dicapai yang selanjutnya tanpa mengesampingkan kebutuhan psikologis dan spiritual juga sangat penting diberikan. Virginia Henderson melalui model konsep teorinya 14 dasar kebutuhan pasien telah menguraikan kebutuhan pasien secara rinci, dimana komponen kebutuhan dasar dari yang pertama sampai yang kesembilan adalah komponen fisiologis. Kebutuhan dasar kesepuluh adalah aspek psikologis yaitu berkomunikasi dan emosi. kebutuhan dasar kesebelas aspek spiritual dan kebutuhan dasar keduabelas sampai keempat belas adalah social yang berorientasi pada pekerjaan dan rekreasi. Dalam perjalanannya model konsep teori Virginia Henderson ini dipengaruhi oleh teori kebutuhan dasar manusia menurut Abraham Maslow yang telah banyak mempengaruhi teori-teori di bidang berbeda. Lima kebutuhan dasar manusia menurut Abraham Maslow adalah 1. Kebutuhan Fisiologis, 2. Kebutuhan Keamanan, 3. Kebutuhan Cinta, sayang dan kepemilikan, 4. Kebuthan harga Diri dan yang tertinggi adalah 5. Kebutuhan Aktualisasi diri.

Teori keperawatan mencakup banyak hal atau bersifat universal khususnya tentang kebutuhan spiritual yang salah satunya telah lama disampaikan oleh Virginia Henderson dalam teorinya 14 kebutuhan dasar manusia. Walaupun model konsep teori Virginia Henderson dipengaruhi oleh kebutuhan dasar manusia berdasarkan hirarki Maslow ada yang sedikit berbeda yaitu kebutuhan pada keyakinan atau spiritual. Jika Maslow memasukkan kebutuhan spiritual menjadi salah satu hirarkinya maka kebutuhan spiritual akan menjadi piramida tertinggi diantara kebutuhan yang telah dikonsepkan sebelumnya, karena dalam menghadapi pasien atau orang sakit khususnya gangguan Kardiovaskular masalah spiritual merupakan 
sentuhan yang sangat berarti dan mempengaruhi keefektifan pemberian asuhan khsusnya kebutuhan fisiologis, artinya kebutuhan spiritual mempengaruhi penatalaksanaan dalam rangka memenuhi kebutuhan fisiologis pasien yang memang menjadi hal utama dalam penanganan pasien dengan gangguan Kardiovaskular khususnya pada fase akut (Safri, 2014). Maka dari peneliti tertarik untuk mengetahui gambaran asuhan keperawatan dimensi spiritual yang telah dilaksanakan oleh perawata dalam melaksanakan tugasnya dalam pengkajian danintervensi khusus untuk kebutuhan spiritual pada pasien gangguan Kardiovaskular yang dilengkapi dengan penerapan. Harapannya melalui penelitian ini peran perawat sebagai pemberi asuhan yang holistik dapat dicapai dan mampu diterapkan dengan mudah dan berkesinambungan.

\section{METODE PENELITIAN}

Desain penelitian yang digunakan adalah deskriptif dengan metode observasional dan pengambilan Sampel dalam penelitian ini dengan menggunakan teknik total sampling yaitu berjumlah 16 responden yang merupakan perawat di ruang rawat inap dengan gangguan kardiovaskuler khususnya ruang CVCU RSUD Arifin Achmad. Instrumen yang digunakan untuk penelitian ini lembar kuisioner dan wawancara tentang intervensi asuhan keperawatan dimensi spiritual berdasarkan NANDA, NIC dan NOC.
HASIL

Tabel 1

Distribusi responden berdasarkan usia

\begin{tabular}{cccccc}
\hline Variabel & $\mathbf{N}$ & Mean & SD & $\begin{array}{c}\text { Minimal- } \\
\text { Maksimal }\end{array}$ & $\begin{array}{c}\mathbf{9 5} \\
\mathbf{\%} \\
\mathbf{C I}\end{array}$ \\
\hline Usia & 16 & 35,94 & 6,698 & $28-51$ & \\
\hline
\end{tabular}

Tabel 1 didapatkan nilai rata-rata usia responden adalah 35,94 dengan standar deviasi 2,769 dan usia tertinggi adalah 51 tahun dan usia terendah 28 tahun.

\section{Karakteristik Responden}

Tabel 2

Karakteristik responden berdasarkan jenis kelamin, pendidikan, pelatihan dan masa kerja

\begin{tabular}{|c|c|c|c|c|}
\hline \multirow[t]{2}{*}{ Variabel } & \multicolumn{2}{|c|}{ Frekuensi } & \multicolumn{2}{|c|}{ Total } \\
\hline & $\mathrm{n}$ & $\%$ & $\mathrm{~N}$ & $\%$ \\
\hline $\begin{array}{ll} & \text { Jenis Kelamin } \\
\text { - } & \text { Laki-laki } \\
\text { - } & \text { Perempuan } \\
\end{array}$ & $\begin{array}{r}3 \\
13 \\
\end{array}$ & $\begin{array}{l}18,8 \\
81,3 \\
\end{array}$ & 16 & 100 \\
\hline \begin{tabular}{ll} 
& \multicolumn{1}{c}{ Pendidikan } \\
- & $\mathrm{D} 3 /$ Vokasional \\
- & $\mathrm{S} 1+$ Ners \\
\end{tabular} & $\begin{array}{r}13 \\
3 \\
\end{array}$ & $\begin{array}{l}81,3 \\
18,8 \\
\end{array}$ & 16 & $\begin{array}{c}100 \\
\%\end{array}$ \\
\hline \begin{tabular}{ll} 
& \multicolumn{1}{c}{ Pelatihan } \\
- & Nanda,NOC/NIC \\
- & ESQ \\
- & Lain-lain \\
\end{tabular} & $\begin{array}{c}0 \\
0 \\
16 \\
\end{array}$ & $\begin{array}{c}0 \\
0 \\
100 \\
\end{array}$ & 16 & $\begin{array}{c}100 \\
\%\end{array}$ \\
\hline $\begin{aligned} & \text { Masa Kerja } \\
\bullet \quad & <5 \text { tahun } \\
\cdot \quad & >5 \text { tahun }\end{aligned}$ & $\begin{array}{c}0 \\
16\end{array}$ & $\begin{array}{c}0 \\
100 \%\end{array}$ & 16 & $\begin{array}{c}100 \\
\%\end{array}$ \\
\hline $\begin{array}{l}\text { Rohaniawan } \\
\text { - } \quad \text { Ada } \\
\text { - Tidak Ada }\end{array}$ & $\begin{array}{c}16 \\
0\end{array}$ & $\begin{array}{c}100 \% \\
0\end{array}$ & 16 & $\begin{array}{c}100 \\
\%\end{array}$ \\
\hline $\begin{array}{l}\text { Buku bimbingan } \\
\text { spiritual } \\
\text { - Ada } \\
\text { - Tidak Ada }\end{array}$ & $\begin{array}{c}3 \\
13\end{array}$ & $\begin{array}{l}18,8 \% \\
81,3 \%\end{array}$ & 16 & $\begin{array}{c}100 \\
\%\end{array}$ \\
\hline
\end{tabular}

Tabel 2 menunjukkan karakteristik responden berdasarkan jenis kelamin, Pelatihan yang pernah diikuti dan masa kerja. Pada penelitian ini, mayoritas responden berjenis perempuan yaitu sebanyak 13 
Safri $^{1}$,Sofiana Nurchayati ${ }^{2}$, Siti Rahmalia ${ }^{3}$,Gambaran Asuhan Keperawatan Dimensi Spiritual Di Ruangan Kardiovaskuler Rsud Arifin Achmad

responden $(81,3 \%)$. Berdasarkan pendidikan terakhir mayoritas pendidikan D3 Keperawatan/vocasional sebanyak 13 responden $(81,3 \%)$. Berdasarkan pelatihan yang pernah diikuti yaitu 16 orang (100\%) belum pernah mengikuti pelatihan NANDA NIC NOC dan pelatihan di bidang spiritual lainnya. Dari tabel di atas juga diketahui bahwa rumah sakit telah memiliki rohaniawan yang bertugas untuk memberikan nasihat spiritual kepada pasien, namun Rumah Sakit belum memiliki buku khusus bimbingan spiritual untuk pasien

\section{Gambaran asuhan keperawatan dimensi} spiritual di Ruang Kardiovaskuler RSUD Arifin Achmad

Diagram 1

Gambaran asuhan keperawatan dimensi spiritual berdasarkan kebiasaan mengajak pasien untuk berdoa

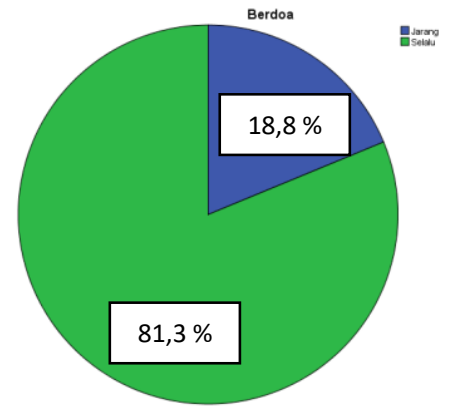

Dari diagram 1 diketahui bahwa 18,3\% perawat di Ruangan Kardiovaskuler jarang mengajak pasien untuk selalu berdoa dan 81,3 $\%$ selalu meminta pasien untuk berdoa demi kesembuhannya..

\section{Diagram 2}

Gambaran asuhan keperawatan dimensi spiritual berdasarkan kebiasaan mengucapkan salam sebelum masuk ruang perawatan

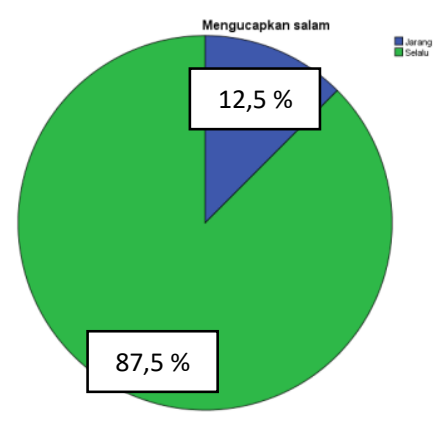

Dari diagram 2 diketahui bahwa 12,5\% perawat di Ruangan Kardiovaskuler jarang mengucapkan salam sebelum masuk ke ruang perawatan dan 87,5 \% selalu mengucapkan salam sebelum masuk ke ruang perawatan.

Diagram 3

Gambaran asuhan keperawatan dimensi spiritual berdasarkan kebiasaan berbagi perasaan dengan pasien

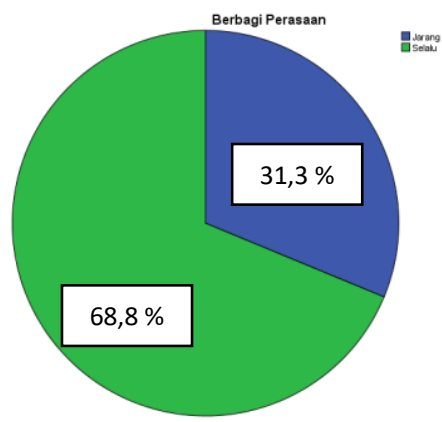

Dari diagram 3 diketahui bahwa 31,3\% perawat di Ruangan Kardiovaskuler jarang berbagi perasaan dengan pasie di ruang perawatan dan $68,8 \%$ selalu berbagi perasaan dengan pasien di ruang perawatan.

Diagram 4

Gambaran asuhan keperawatan dimensi spiritual berdasarkan kebiasaan memberikan lingkungan yang aman dan nyaman.

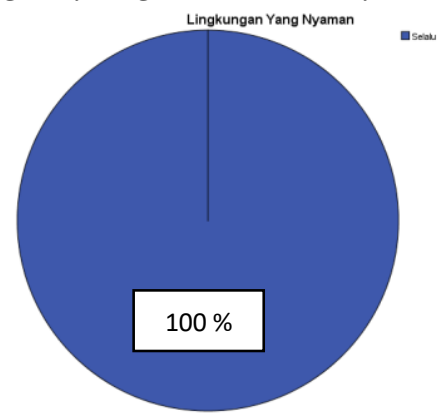


Dari gambar diatas diketahui bahwa 100 $\%$ atau semua perawat di Ruangan Kardiovaskuler memberikan lingkungan yang aman dan nyaman kepada pasien.

\section{Diagram 5}

Gambaran asuhan keperawatan dimensi spiritual berdasarkan kebiasaan mengingatkan waktu-waktu ibadah kepada pasien

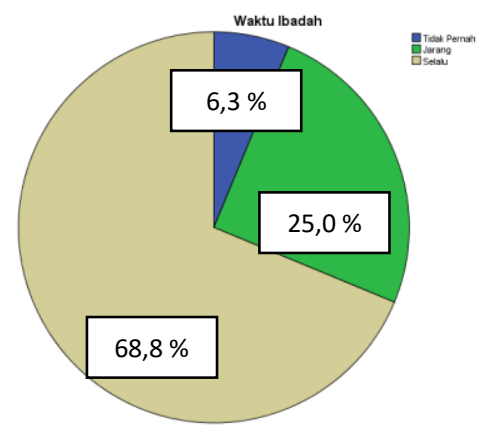

Dari gambar diatas diketahui bahwa 6,3 $\%$ perawat di Ruangan Kardiovaskuler tidak pernah mengingatkan ke pasien tentang waktuwaktu ibadah, sedangkan 25,0 \%perawat jarang mengingatkan ke pasien tentang waktuwaktu ibadah dan $68,8 \%$ selalu mengingatkan ke pasien tentang waktu-waktu ibadah.

Diagram 6

Gambaran asuhan keperawatan dimensi spiritual berdasarkan kebiasaan mengorientasikan fasilitas ibadah yang tersedia kepada pasien

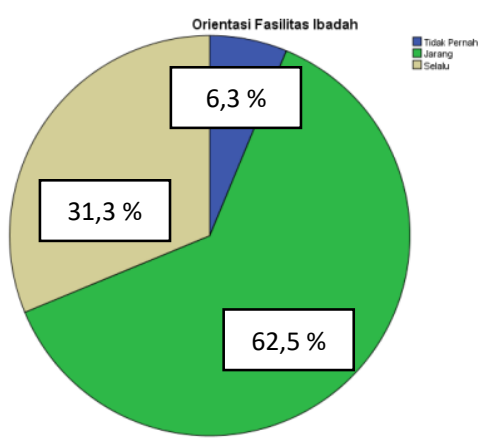

Dari gambar diatas diketahui bahwa 6,3 $\%$ perawat di Ruangan Kardiovaskuler tidak pernah mengorientasikan fsilitas ibadah yang tersedia, sedangkan $62,5 \%$ perawat jarang mengorientasikan fsilitas ibadah yang tersedia dan $31,3 \%$ selalu mengorientasikan fsilitas ibadah yang tersedia di Rumah Sakit.

Diagram 7

Gambaran asuhan keperawatan dimensi spiritual berdasarkan kebiasaan memberikan terapi komplementer kepada pasien.

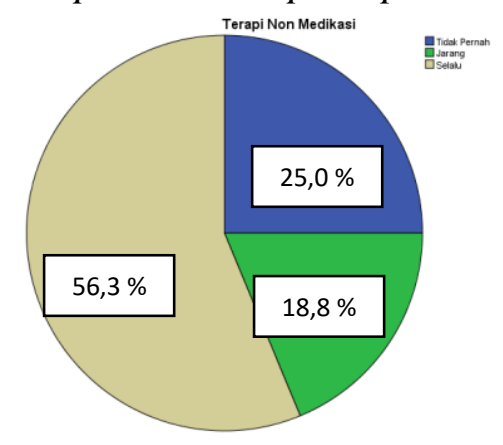

Dari gambar diatas diketahui bahwa 25,0 $\%$ perawat di Ruangan Kardiovaskuler tidak pernah memberikan terapi komplementer, sedangkan $18,8 \%$ perawat jarang memberikan terapi komplementer dan 56,3\% selalu terapi komplementer di Rumah Sakit

Diagram 8

Gambaran asuhan keperawatan dimensi spiritual berdasarkan kebiasaan merencanakan ritual ibadah bersama pasien

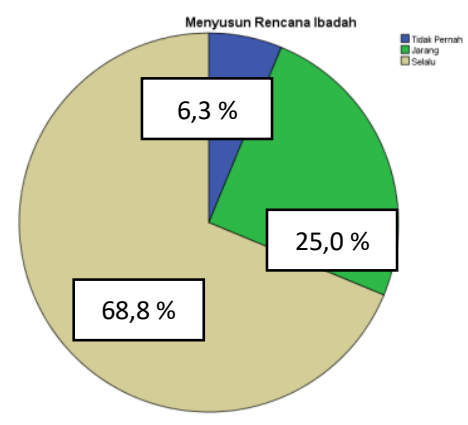


Safri $^{1}$,Sofiana Nurchayati ${ }^{2}$, Siti Rahmalia ${ }^{3}$,Gambaran Asuhan Keperawatan Dimensi Spiritual Di Ruangan Kardiovaskuler Rsud Arifin Achmad

Dari gambar diatas diketahui bahwa 6,3 \% perawat di Ruangan Kardiovaskuler tidak pernah menyusun bersama pasien tentng rencana ritual ibadah yang akan dilaksanakan, sedangkan $25,0 \%$ perawat jarang menyusun bersama pasien tentng rencana ritual ibadah yang akan dilaksanakan dan 68,8 \% selalu menyusun bersama pasien tentng rencana ritual ibadah yang akan dilaksanakan selama pasien dirawat.

Diagram 8

Gambaran asuhan keperawatan dimensi spiritual berdasarkan kebiasaan memberikan waktu ibadah kepada pasien

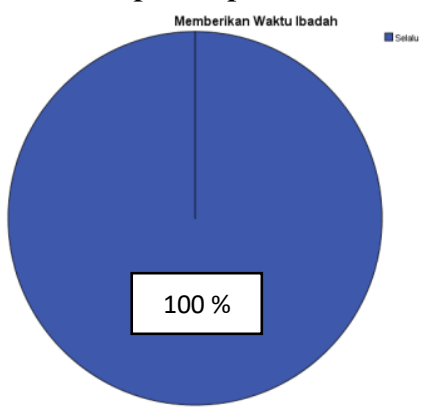

Dari gambar diatas diketahui bahwa $100 \%$ atau semua perawat selalu memberikan kesempatan kepada pasien untuk beribadah.

\section{Diagram 9}

Gambaran asuhan keperawatan dimensi spiritual berdasarkan kebiasaan perawatan menjelang ajal

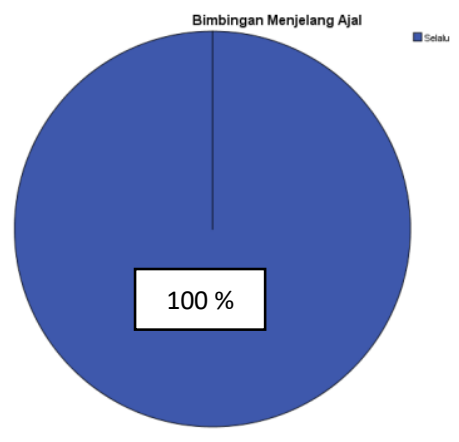

Dari gambar diatas diketahui bahwa 100 $\%$ atau semua perawat di Ruangan Kardiovaskuler selalu memberikan perawatn menjelang ajal seperti membimbing pasien saat sakarotul maut (talkin).

Diagram 10

Gambaran asuhan keperawatan dimensi spiritual berdasarkan kebiasaan melakukan pengkajian dimensi spiritual

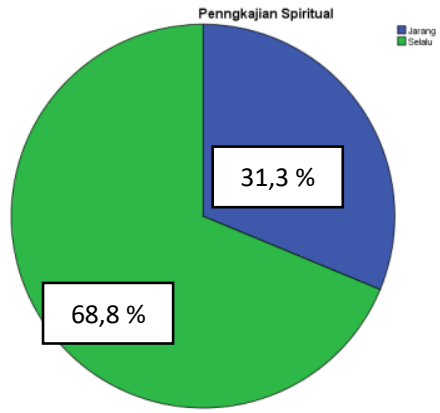

Dari gambar diatas diketahui bahwa 31,3 $\%$ perawat jarang melakukan pengkajian dimensi spiritual pasien dan $68,8 \%$ selalu melakukan pengkajian dimensi spiritual pasien.

Diagram 11

Gambaran asuhan keperawatan dimensi spiritual berdasarkan kebiasaan mengangkat diagnosa kepeawatan dimensi spiritual

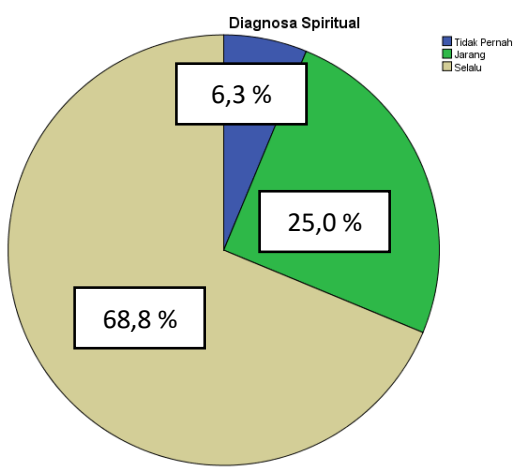

Dari gambar diatas diketahui bahwa 6,3 $\%$ perawat di Ruangan Kardiovaskuler tidak pernah mengangkat diagnosa keperawatan dimensi spiritual, sedangkan $25,0 \%$ perawat 
jarang mengangkat diagnosa keperawatan dimensi spiritual dan $68,8 \%$ selalu mengangkat diagnosa keperawatan dimensi spiritual pasien.

\section{PEMBAHASAN}

\section{Karakteristik Responden}

Usia respomden yang merupakan perawat yang berada di ruang CVCU merupakan usia yang produktif, artinya dilihat dari rata-rata usia yaitu 35,94 tahun dengan rentang antara usia 28-50 tahun. Terdapat beberapa tingkatan usia pada responden ini, namun jika dilihat dari rata-rata masih dalam rentang usia produktif yaitu 20-35. Berdasarkan jenis kelamin mayoritas responden berjenis kelamin laki-laki, secara langsung mungkin tidak berhubungan langsung dengan asuhan keperawatan spiritual, tetapi kecenderungan perawat didominasi oleh perempuan. Hal ini memberikan keuntungan bahwa perempuan memiliki sifat keibuan yang menjadi dasar lahirnya profesi keperawatan.

Pendidikan formil responden lebih banyak pada pendidikan vokasi, ini juga menetuan kualitas pelayanan keperawatan khususnya dimensi spiritual. Namun demikian asuhan keperawatan dimensi spiritual tidaklah berarti memiliki pendidikan tinggi maka akan tinggi pula kualitas asuhan keperawatannya. Seharusnya perawat harus dimotivasi lagi untuk mendapatkan pendidikan yang lebih baik sehingga segala aspek yang diperlukan dalam memberikan asuhan keperawatan dapat masuk ke dalam diri seorang perawat, khsusnya asuhan keperawatan spiritual.

Improvisasi seorang perawat dapat dilakukan juga melalui pelatihan-pelatihan di bidang keperawatan, terlebih dalam melaksanakan asuhan keperawatan telah memiliki panduan yaitu Nursing Outcome Clasification dan Nursing Intervention Clasification (NOC/NIC), namun dari seluruh responden belum pernah mengikuti pelatihan di bidang ini ataupun khusus di bidang spiritual seperti Emotional Spiritual Quation (ESQ). Diharapkan dengan mengikuti pelatihan ini, kecerdasan spiritual perawat dapat ditingkatkan dan memilki makna dalam menjalankan tugas sebagai perawat. Dalam tulisannya, safri (2014) mengatakan bahwa tidak akan maksimal asuhan keperawatan dimensi spiritual yang diberikan, jika perawat tidak memilki kecerdasan spiritual yang baik. Ciri-ciri kecerdasan spiritual perawat yang baik salah satunya adalah kecenderungan seorang pasien ingin dirawat oleh perawat tertentu.

Masa kerja seorang perawat mempengaruhi sikap dan prilakunya dalam memberikan asuhan keperawatan, mengingat masa kerja responden seluruhnya lebih dari 5 (lima) tahun. Ketersediaan ustadz/rohaniawan sebagai petugas pemberi penasehat spiritual merupakan hal yang penting di sebuah layanan kesehatan seperti rumah sakit, namun dengan meningkatkan kualitas kecerdasan spiritual perawat hal ini dapat teratasi mengingat 
Safri $^{1}$,Sofiana Nurchayati ${ }^{2}$, Siti Rahmalia ${ }^{3}$,Gambaran Asuhan Keperawatan Dimensi Spiritual Di Ruangan Kardiovaskuler Rsud Arifin Achmad

selama 24 jam pasien bersama perawat yang memberikan asuhan keperawatannya serta asuhan kolaborasi. RSUD Arifin Achmad juga belum memiliki buku panduan asuhan keperawatan dimensi spirital. Buku panduan ini berguna untuk mengingatkan perawat akan kebutuhan pasiennya dalam memenuhi kebutuhan aspiritual pasien tersebut.

\section{Asuhan Keperawatan Dimensi Spiritual}

Dan orang yang beriman, laki-laki dan perempuan, sebagian mereka (adalah) menjadi penolong bagi sebagian yang lain. Mereka menyeruruh (mengerjakan) yang ma'ruf, mencegah yang munkar, mendirikan sembahyang, menunaikan zakat dan mereka taat kepada Allah dan RasulNya." (Q.S. At-Taubah: 71)

“...Dan tolong menolonglah kamu dalam mengerjakan kebaikan dan taqwa, dan jangan tolong menolong dalam berbuat dosa dan pelanggaran, dan bertawalah kamu kepada Allah, sesungguhnya Allah maha berat siksa-Nya." (Q.S. Al-Maaidah : 2) .

Dua kutipan ayat di atas mengisyaratkan kepada kita perawat khususnya perawat islam bahwa pekerjaan menjadi perawat adalah sesuatu yang sangat mulia dan bernilai ibadah. Untuk itu dalam pelaksanaannya perawat sebaiknya memperhatikan hal-hal yang berkenaan dengan kebuutuhan siritual pasien seperti berdo`a, shalat dan ibadah lainnya. Dalam penelitian ini diketahui bahwa mayoritas perawat sering mengajak pasiennya untuk berdo`a sebelum memulai aktivitas, mengucapkan salam dan selalu berbagi perasaan kepada pasien yang dirawatnya.
Dengan melakukan hal-hal tersebut di atas akan menambah kebahagiaan dan motivasi kepada pasien untuk menjalani perawatan di rumah sakit.

Manusia merupakan makhluk yang memiliki bio-psiko-sosio dan cultural yang berespon secara holistik dan unik terhadap perubahan kesehatan atau pada keadaan kritis. Aspek spiritual merupakan bagian integral dan interaksi perawat dengan klien. Perawat berupaya memenuhi kebutuhan spiritual klien walaupun tidak seagama (McSherry, 2006).

Lingkungan yang nyaman dan aman, mengingatkan waktu-waktu ibadah, memberikan terapi komplementer khususnya terapi stimulasi spiritual dan bersama pasien merencanakan ritual keagamaan merupakan hal yang penting dan harus dilakukan oleh perawat bersama pasien, mengingat hal tersebut merupakan intervensi yang telah diatur dalam NANDA, NIC/NOC dalam menyelesaikan masalah keperawatan dimensi spiritual. Teori Stoll, 1989 konsep spiritual mencakup 2 demensi yaitu demensi vertikal yaitu hubungan dengan tuhan yang maha esa atau yang maha tingi yang menuntun kehidupan seseorang, sedangkan demensi horizontal yaitu hubungan seseorang dengan din sendiri, orang lain dan Iingkungan, kedua demensi tersebut dilaksanakan secara kontinu.

$$
\text { Berdasarkan penerapan asuhan }
$$
keperawatan dimensi spiritual dalam hal pengkajian dan penegakan diagnosa asuhan spiritual, menurut responden telah melakukan 
pengkajian dan menegakkan diagnosa tersebut. Namun dalam penelitian ini belum dirincikan apakah pengkajian sesuai dengan format dan redaksi diagnosa keperawatan sesuai dengan panduan yaitu NOC (Nursing Outcome Clasification/ Nursing Intervention Clasification).

Perawatan menjelang ajal merupakan intervensi yang sering dilakukan oleh responden sebagai perawat di ruang intensif. Hal ini sangat penting mengingat pasienpasien yang dalam kondisi kritis akan lebih bermakna jika dilakukan bimbingan saat ajal seperti mentalkin pasien yang beragama islam atau berdoa bagi pasien beragama kristen. Intervensi ini dilakukan agar pasien meninggal dalam kondisi husnul khotimah atau mati dengan damai.

\section{SIMPULAN}

Secara umum disimpulkan bahwa dari karakteristik usia diketahui usia responden masuk dalam kategori usia produktif. Dilihat dari karakteristik jenis kelamin mayoritas perempuan, dan mayoritas pendidikan D3 Keperawatan/vocasional, sedangkan lama bekerja mayoritas adalah lebih dari 5 tahun serta jenis pelatihan mayoritas belum pernah mengikuti pelatihan NANDA NIC NOC ataupun pelatihan spiritual seperti ESQ. Fasilitas di rumah sakit menunjukkan bahwa adanya rohaniawan yaitu petugas khusus dalam memenuhi kebutuhan spiritual pasien dan belum memiliki buku panduan ibadah apsien di rumah sakit. Faktor demografi ini sangat berpengaruh terhadap penatalaksanaan asuhan keperawatan dimensi spiritual pasien.

Berdasarkan penerapan asuhan keperawatan dimensi spiritual dalam hal pengkajian dan penegakan diagnosa asuhan spiritual, menurut responden telah melakukan pengkajian dan menegakkan diagnosa tersebut. Namun dalam penelitian ini belum dirincikan apakah pengkajian sesuai dengan format dan redaksi diagnosa keperawatan sesuai dengan panduan yaitu NOC (Nursing Outcome Clasification/ Nursing Intervention Clasification).

Perawatan menjelang ajal merupakan intervensi yang sering dilakukan oleh responden sebagai perawat di ruang intensif. Hal ini sangat penting mengingat pasienpasien yang dalam kondisi kritis akan lebih bermakna jika dilakukan bimbingan saat ajal seperti mentalkin pasien yang beragama islam atau berdoa bagi pasien beragama kristen. Intervensi ini dilakukan agar pasien meninggal dalam kondisi husnul khotimah atau mati dengan damai

\section{SARAN}

Rumah sakit sebaiknya memiliki buku panduan bimbingan ibadah pasien sehingga perawat juga terfasilitasi untuk dapat memberikan asuhan keperawatan spiritual pasien tanpa mengandalkan rohaniawan yang belum tentu paham betul terhadap kondisi pasien yang dirawat. 
Safri $^{1}$,Sofiana Nurchayati ${ }^{2}$, Siti Rahmalia ${ }^{3}$,Gambaran Asuhan Keperawatan Dimensi Spiritual Di Ruangan Kardiovaskuler Rsud Arifin Achmad

\section{DAFTAR PUSTAKA}

Barnum, B. S. (2006). Spirituality in Nursing From Traditional to New Age (2nd Edition ed.). New York: Springer Publishing Company, Inc.

Black, J.M., \& Hawks, J.H. (2009). Medical surgical nursing : Clinical management for positive outcomes (8th ed). Philadelphia : Saunders Elsevier

Brunner and Suddarth. (2002). Buku Ajar Keperawatan Medikal Bedah Edisi 8. EGC ; Jakarta, Indonesia

Bulechek, G. M., Butcher, H. K., \& Dochterman, J. M. (2013). Nursing Intervention Classification (NIC) (sixth ed.). St. Louis, Missouri: Mosby Inc.; Elsevier Inc.

Draper, P. (2012). An integrative review of spiritual assessment: implications for nursing management. $J$ Nurs Manag, 20(8), 970-980. doi: 10.1111/jonm. 12005

Fitzpatrick, J.J. \& Whall, A.L. (1989). Conceptual models of nursing. $\left(2^{\text {nd }}\right.$ edition). California: Appleton \& Lange

McSherry, W. (2006). Making Sense of Spirituality in Nursing and Health Care Practice An Interactive Approach (Second Edition ed.). London and Philadelphia: Jessica Kingsley Publishers.

Moorhead, S., Johnson, M., Maas, M. L., \& Swanson, E. (2013). Nursing Outcomes Classification (NOC) (fifth ed.). St. Louis, Missouri: Mosby Inc.; Elsevier Inc.

Parker, M.E (2005).Nursing Theories \& Nursing Practice. ( $2^{\text {nd }}$ edition). Philadelphia,F.A Davis Company
Potter, P.A., \& Perry, A.G. (2006) Buku ajar fundamental keperawatan : Konsep, proses dan praktik (Edisi 4, Vol 2). (Yasmin, dkk, Alih Bahasa). Jakarta : EGC

Price \& Wilson. (2006). Patofisiologi konsep klinis proses-proses penyakit (Vol 2). (Peter Anugrah, Alih Bahasa). Jakarta : EGC

Reed, P.G. (2004). Perspectives on Nursing Theory $\left(4^{\text {th }}\right.$ edition). Philadhelpia: Lippincott Williams \& Wilkins

Rilantono, Lily I. (2012). 5 Rahasia Penyakit Kardiovaskular (DVK). Badan penerbit FKUI; Jakarta

Safri. (2014). Laporan kegitan residensi keperawatan pada pasien gangguan sistem kardiovaskuler dengan pendekatan teori Virginia Henderson di rumah sakit jantung dan pembuluh darah harapan kita Jakarta. Jakarta. FIKUI

Smeltzer, S.C \& Bare, B.G. (2008). Textbook of medical surgical nursing. Philadelphia : Lippincot Williams \& Wilkins

Sodikin. (2012). Pengaruh terapi bacaan AlQuran melalui media audio terhadap respon nyeri pasien post operasi hernia di Rumah Sakit Cilaca. Jakarta FIKUI

Supriyono, Mamad (2008) Faktor-Faktor Risiko Kejadian Penyakit Jantung Koroner (PJK) Pada Kelompok Usia < 45 Tahun. (Studi Kasus di RSUP Dr. Kariadi Semarang dan RS Telogorejo Semarang). Jurnal Epidemiologi

Timmins, F., \& Kelly, J. (2008). Spiritual assessment in intensive and cardiac care nursing. Nurs Crit Care, 13(3), 124-131. doi: 10.1111/j.1478-5153.2008.00276.

Tomey, A.M. \& Alligood, M.R. (2006). Nursing Theorists and their work. $\left(6^{\text {th }}\right.$ edition).

America:

Mosby 